\title{
The Evidence Theory and Methodology of Axiological Completions in the Context of Philological Training
}

\author{
Liuba Botezatu \\ PhD, Professor, Department of Romanian Philology, University of State Comrat, Republic of Moldova \\ liuba.botezatu@yahoo.com
}

\begin{abstract}
The first step of evidencing the axiological completions occurs, in our interpretation, at the level of "Retroaction in the context of linguistic and literary education" as right as a modern teaching technology in the curricular pre-university system. The second stage (bachelor-master), of completing evidence, in perfect ascension (of the same interpretation L.B.) occurs at co-reporting level: Principle of Global Axiology - Methodology of Evidencing the Axiological Completions engagement on a new level of becoming: training the philologist teacher.

"Happiness lies in to know yourself": the stylistic matrix of the biased nation, the mother language - the language of raw ascensions into the great spirituality; the own possibilities of opening - manifestation of self-realization in the universal circuit. Or, this is the primary purpose of participating approaches / engagements in professional plan: training / forming the philologist - philological genetic (bilingual - multi-lingual), philological centrist by vocation.

The joints of the Evidence Methodology of Axiological Completions / MECA in this structural-phenomenal context are, on the one hand, those relating to translation into life of the possibilities / requirements listed, taking preponderance here: the possibility of returning to essence - the ability of ascension through spirituality - the possibility of highlighting the axiological completions, on the other hand - those related to the focus on diversification - information - unification, on the establishment of syntactical highlight of the pertinent datum.
\end{abstract}

\section{Indexing terms/Keywords}

The Evidence Methodology of Axiological Completions; The Logic - Semantic and Functional Principle; The Principle of the Sovereign Inner; The Principle of General / Global Axiology; Retro-action; textual analysis; philological centrist training.

\section{Academic Discipline And Sub-Disciplines}

Methodology; Philology; Philological culture; Didactics; Psychology; Professional Training.

\section{SUBJECT CLASSIFICATION}

Linguistic Subject Classification; Literary Subject Classification; Methodology Subject Classification; Philological Subject Classification; Theory Subject Classification.

\section{TYPE (METHOD/APPROACH)}

Didactic Methodics; Methodological Synthesis.

\section{INTRODUCTION}

"The whole problem of Romania is not only to be, to be in eternity, but also to become. However, how can you turn the being into becoming?" (C. Noica)

\section{RETROACTION AND GRACIOUSNESS IN THE LINGUISTIC AND LITERARY EDUCATION}

The formation of a specific culture of linguistic and literary education focuses on revealing the fullness of the content of the written and talked word, for the purpose of engaging the whole formative - integrative system on retroactivity: on the principle of authenticity of becoming, on the principle of full harmonization; on the principle of Graciousness versus the Principle of Global Axiology, with its ten possibilities/exigencies of completion. (Annex 1). Among which we remind here only three of them: the possibility of returning to the essence, the possibility of ascending through spirituality, the possibility of highlighting the axiological completions, under which we conceptualized the Retroaction as right as a modern technology/methodology of linguistic and literary education. On the other hand, the Retroaction represents an open evolving/evaluative system of revaluating the personality by exercising a triple educational curve: from the present through the past to the future, at the level of Graciousness, an axiological general principle of human awareness, through:

- Tradition and innovation;

- Harmonization of opposites;

- $\quad$ Adjusting the cause by effect;

- $\quad$ Free will. (Certify L. B. [7, p.5; p.45].)

About these and other completing priorities informs us the system of retroactive activities in the pre-university education (school): Table 1, and university education: Table 2. 
"Alimented on the context of linguistic and literary education, the Retroaction as right as a process of natural development, assumes in direct way the ideal responsibility of forming the personality." - our note [6, p.6].

Table 1: Retroaction and Graciousness in the linguistic and literary education of pupils [lbid.6, p.48]

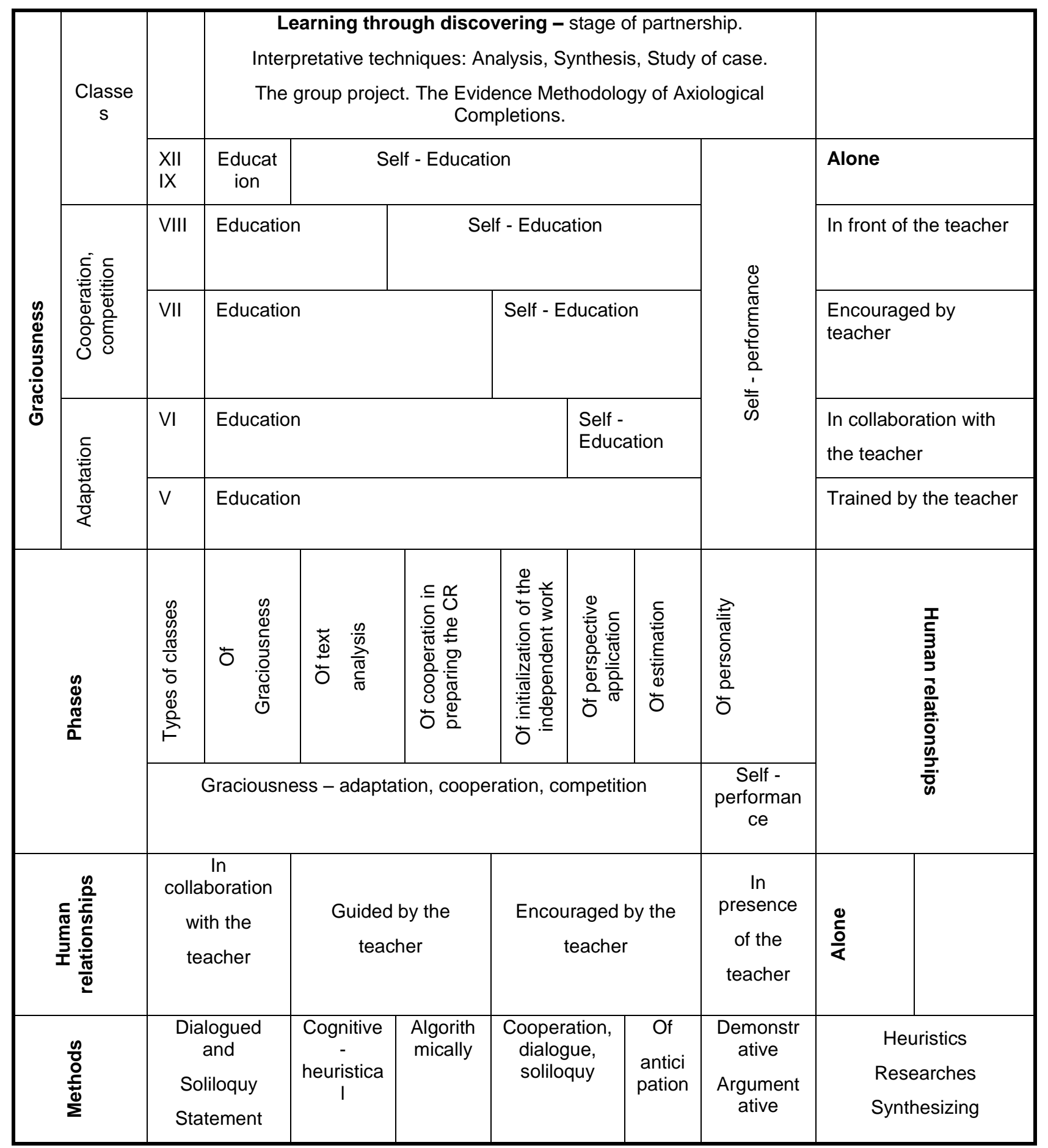

\section{Philological culture, specific interpretative form}

A specific culture of linguistic and literary education (at MECA level), from the beginning, puts in the game the evidence of quality. The language, the communication, are specific ways of highlighting the culture, therefore - the externalization of mind, taking into account that, congenitally, each individual requires two shaping conditions in the externalization of self: the condition of intimate universe - the genetic datum and the condition of the social - reaction to the social environment. If at the level of environment the hegemonic function of representing the collective culture belongs especially to PAG, then, at the individual level of interpretation, it belongs to the principle of sovereign inner / PLS [18]. Both formative indices equally find their place in language, the bearer of the intellectual expression of the disposed one. By synthesis, the both co-reporting agents: individual - society are predestined to co-work reciprocally in the favor of the identity unicity under the 
sign of quality; the evidence bearing its engaging joints in the measure of a qualitative motivation. On the other hand, a notorious philological culture emphasizes the harmonization of defining particularities into a whole. Besides, after the findings of Roger Trigg "The human genetic consciousness not only guarantee the ability to create culture and be influenced by it, but it may be responsible for at least some content of human culture" [36, p.192]. "The culture (in the identity representation - n. n.) produces the environment in which the genes can be submitted on..." [ibid. p.194]. We must affirm that an environment suitable to the modeling / modernization of education is produced by adhering the individual opportunities to the traditions and innovations of the valued time. From this perspective, we propose here the following interactive concept.

\section{TRADITION AND INNOVATION IN DIDACTICS OF LANGUAGE}

\section{Principles. Competences. Methods.}

\section{Objectives and finalities:}

- $\quad$ Correlation PAG - MECA;

- Professional management and arts of education;

- Focusing on the componential triad: knowledge - communication - creativity;

- Formation of a specific culture of professional education.

\section{Principles of identity of becoming in interactive curriculum system:}

- The Principle of Global Axiology: the ten interactive possibilities / Annex 1;

- The logical-semantic and functional principle in the grammar of language;

- $\quad$ The principle of otherness and creativity [21];

- $\quad$ The principle of sovereign inner [18];

- $\quad$ The principle of evidencing the full resignations through MECA [cf. L.B.]

A. Generic competences of inter-trans-disciplinary ensemble: knowing how to ingratiate the valued time and space; knowing to learn to continuously engage yourself to the competitiveness bar; knowing to ingratiate the ten possibilities of the global axiological principle; knowing to rise your authenticity truth to the bar of general axiology; knowing to wear with dignity your divine mandate: Human.

B. Generic competences of professional formation: to project and to realize in a creative way curricular and extracurricular activities; to analyze / to interpret linguistic and literary phenomena in the context of educational approach; to apply appropriate strategies for creativity at following levels: teaching - learning - evaluation - evolving; to form / to practice investigational skills in the field.

\section{Specific competences of professional formation:}

The subject - object of education has to know the terminology and taxonomy of the didactics of Romanian language and literature; to integrate the knowledge of general didactics with those of linguistics and literary theory/history, demonstrating a holistic view over the process of training / skills development; to realize the knowledge transfer by modifying the strategic parameters of evidencing the completions in accordance with the objectives of the afferent content.

\section{The evidence methodology of axiological completions / MECA [13] - a synthesizer phenomenological process of recovering the lost unity [32]:}

- Diagnostic - Forecasting - Monitoring;

- Observation - Analysis - Synthesis;

- Quantity - Quality = the Jump: Human, horizon of mysteries - Human, horizon of the great virtues;

- Integrative Strategies: Method of Returning to the Essence/MRE; Method of Emphatic Analysis/MAE; Method of Structural Analysis/MAS; Method of Returning to the Square of Hypotenuse/ MRPI; Axiomatic Method/MAX; Evidence Method of Axiological Completions/MECA.

- The educational management: constructive knowledge - modifiable intelligence / F. Frumos;

- Academic standardization, modalities of evidencing the axiological completions - methodological subsuming. 
International Journal of Research in Education Methodology

Table 2: The System of Retroactivity EL/EA in the I and II cycle - university education [9, p.16-17]

\begin{tabular}{|c|c|c|c|}
\hline $\begin{array}{c}\text { PAG } \\
\text { The basic } \\
\text { principles of } \\
\text { didactics }\end{array}$ & $\begin{array}{l}\text { Principles of self- } \\
\text { regulated learning }\end{array}$ & Types of lessons & $\begin{array}{l}\text { Strategies, methods, } \\
\text { techniques of work }\end{array}$ \\
\hline \multirow[t]{2}{*}{ Knowledge } & & of graciousness & $\begin{array}{l}\text { Focusing on managerial vectors of } \\
\text { procreation of sensitizer curricular } \\
\text { environment of the competitive } \\
\text { self-evaluation. }\end{array}$ \\
\hline & Active involvement & of textual analysis & Structural analysis \\
\hline \multirow[t]{2}{*}{ Communication } & $\begin{array}{l}\text { Models and } \\
\text { connections }\end{array}$ & $\begin{array}{c}\text { of analysis and synthesis of } \\
\text { the language factors at subject/ } \\
\text { given discipline }\end{array}$ & $\begin{array}{l}\text { Analysis and synthesis } \\
\text { 1. implicit learning } \\
\text { 2. exit in the real environment }\end{array}$ \\
\hline & Informal learning & $\begin{array}{c}\text { advisory, of } \\
\text { concretization/intellectual } \\
\text { substitution }\end{array}$ & $\begin{array}{l}\text { Algorithmization } \\
\text { Implicit learning } \\
\text { Exit in the real environment } \\
\text { Discipleship }\end{array}$ \\
\hline \multirow[t]{3}{*}{ Creativity } & Direct experience & $\begin{array}{l}\text { of synthesizing / awareness } \\
\text { of evolving / evaluation tasks }\end{array}$ & $\begin{array}{l}\text { Applied learning } \\
\text { Display of knowledges } \\
\text { Flexible thinking } \\
\text { Critical thinking }\end{array}$ \\
\hline & Agreeable framework & $\begin{array}{l}\text { Of laboratory - elaborating } \\
\text { and defending the group } \\
\text { projects, portfolios }\end{array}$ & $\begin{array}{l}\text { Personal interaction } \\
\text { Applied thinking }\end{array}$ \\
\hline & Personal reflections & $\begin{array}{l}\text { Free will - evaluation / self- } \\
\text { evaluation of competences }\end{array}$ & $\begin{array}{l}\text { The personal support qiven in } \\
\text { the assumption of a moderated } \\
\text { risk }\end{array}$ \\
\hline $\begin{array}{l}\text { Integrating } \\
\text { competences }\end{array}$ & Agreeable framework & $\begin{array}{l}\text { Evolution / self-evaluation of } \\
\text { self-completions }\end{array}$ & Social effectiveness \\
\hline $\begin{array}{l}\text { Possibility of } \\
\text { creative re- } \\
\text { consignation }\end{array}$ & Disciplinary & Inter-disciplinary & Trans-disciplinary \\
\hline
\end{tabular}


Table 3: The syntax of Romanian language. The disciplinary curricula.

Subject 6. Study of case: The logic-semantic and functional principle in the syntax of Romanian language.

\begin{tabular}{|c|c|}
\hline Objectives & Units of content \\
\hline $\begin{array}{l}\text { The students will be capable to: } \\
\text { - } \quad \text { sustain the project of group; } \\
\text { - landmark on the logic-semantic and functional } \\
\text { principle (sentence - text-phrase at subjective - } \\
\text { predicative level) in correlation with the Global } \\
\text { Axiological Principle - text/inter-text - subject- } \\
\text { predicate: the possibility of returning to essence } \\
\text { - the possibility of ascension through } \\
\text { spirituality; } \\
\text { observe, analyze, synthesize / find the subjects } \\
\text { of professional interest: subject - predicate - } \\
\text { philosophy and axiology of education - the } \\
\text { syntax of Romanian language; } \\
\text { focus on the evidence of completions; } \\
\text { - focus on themes of reflections: } \\
\text { 1. The correlation PLSF-PAG-PLS in the Syntax of } \\
\text { Romanian language. } \\
\text { 2. The possibility of returning to the essence. } \\
\text { 3. The correlation engaged sentence - engaged } \\
\text { phrase - text. } \\
\text { The logic-semantic and functional principle and } \\
\text { 1. The Global Axiological Principle - The Evidence } \\
\text { Method of Axiological Completions. } \\
\text { the of phrases in the text. }\end{array}$ & $\begin{array}{l}\text { Study of case - landmark: } \\
\text { 1. Types of subjects and the subordinated subjective } \\
\text { sentence. } \\
\text { 2. Types of predicates and the subordinated } \\
\text { predicative sentence. } \\
\text { 3. The subject of quality and the text as a complex } \\
\text { unity of content. } \\
\text { 4. Attitudes. Synthesizing at level of tradition and } \\
\text { innovation. } \\
\text { Updating objectives focused on the forming of } \\
\text { competences. } \\
\text { The study of class marks. } \\
\text { Documentation from bibliographical sources. } \\
\text { Consultation of dictionaries. Deciphering/commenting of } \\
\text { key terms: syntax, gearing, logic-semantic and functional } \\
\text { principle; predicative center, predicativity, predication; } \\
\text { subjectivity - subjection - subject of quality; text. } \\
\text { Realization of compared study - reference to the name of } \\
\text { the scientists in the field. } \\
\text { Taking of decisions for techniques of interactive work } \\
\text { opposite to the } 8 \text { (eight) principles of autonomy/self- } \\
\text { regulated learning. } \\
\text { Evaluation of communications based on observation, } \\
\text { analysis, synthesis, solving of problem situations. } \\
\text { Presentation of various informational sources. }\end{array}$ \\
\hline
\end{tabular}

Table 4:

\begin{tabular}{|c|c|c|c|c|}
\hline \multicolumn{5}{|c|}{ Forms and organizational strategies of didactic activity } \\
\hline N/R & $\begin{array}{c}\text { Form of } \\
\text { organization/types } \\
\text { of evaluation }\end{array}$ & $\begin{array}{l}\text { No. of } \\
\text { classes }\end{array}$ & $\begin{array}{c}\text { Strategies and } \\
\text { predominant } \\
\text { didactic activities }\end{array}$ & Bibliography \\
\hline 1. & Study of case & 2 & $\begin{array}{l}\text { Sustaining of group } \\
\text { projects }\end{array}$ & $\begin{array}{l}\text { Budagov, R.A.,"'Filologhia v sovremennoi boribe idei / } \\
\text { Filologhiceschie nauchi"',1984, N3.Str.16.) }\end{array}$ \\
\hline 2. & $\begin{array}{l}\text { Individual activity } \\
\text { Group activity }\end{array}$ & 2 & $\begin{array}{l}\text { Work over } \\
\text { text/fragments of } \\
\text { text } \\
\text { Tasks of group } \\
\text { analysis }\end{array}$ & $\begin{array}{l}\text { Butuc, Petru,"Predicatul angrenat în limba } \\
\text { română".Ed. Iulian, Chișinău, } 2004 . \\
\text { Butuc, Petru,"Studii de gramatică și istorie a limbii } \\
\text { române literare", Chișinău, } 2012 \text {. } \\
\text { Butuc, Petru, "Concepții lingvistico-filozofice }\end{array}$ \\
\hline
\end{tabular}




\begin{tabular}{|c|c|c|c|c|}
\hline \begin{tabular}{|l}
3. \\
\end{tabular} & $\begin{array}{l}\text { Current evaluation } \\
\text { Self-evaluation } \\
\text { Evidence of } \\
\text { Axiological } \\
\text { Completions }\end{array}$ & 2 & $\begin{array}{l}\text { Reciprocal } \\
\text { evaluation of } \\
\text { articles for the } \\
\text { portfolio. } \\
\text { Modalities of } \\
\text { appreciation of } \\
\text { group projects. }\end{array}$ & 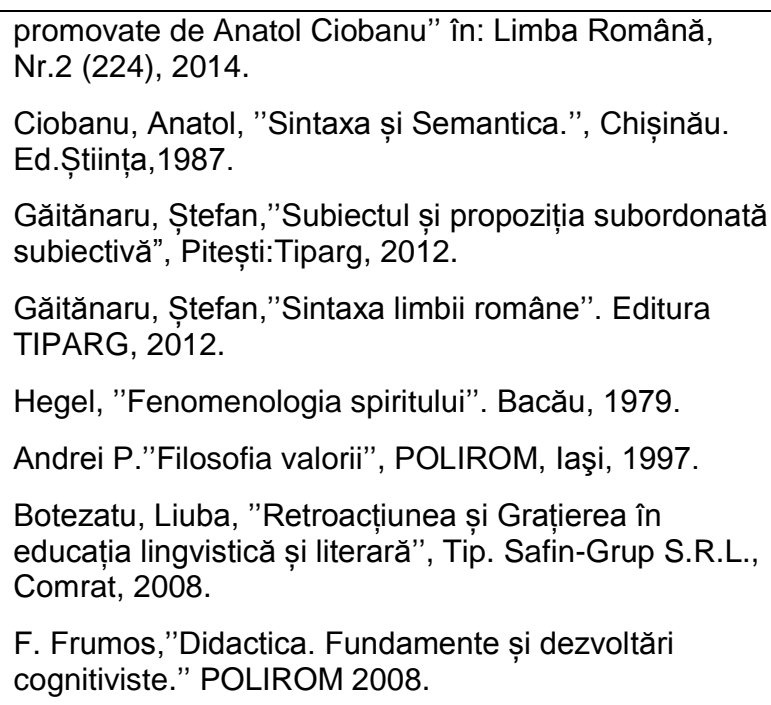 \\
\hline
\end{tabular}

\section{Completing references}

The researches over the vieren poetry (Grigore Vieru's poetry) - Longing of mother (Dor de mamă) and also over the druțian prose (Ion Druță's prose) - Leaves of longing (Frunze de dor) proves that the interrelation subject - predicate, therefore, the subjection - predication interrelationship, relies on the interaction of the two syntax plans taken in consideration: the reality plan and the fictional plan related to the stylistic construction of the representative content. The first plan requires the involvement of logic / value judgment on the position of the subjection-predication: total, binary, partial; the second plan, the fictional, involves the determination of advantages of the same interdependence from the affective, emotional-aesthetic point of view, as a unique measure of how much being fits in the word. Or, the unitary ensemble (reality-fiction) must characterize the priorities of axiological global principle of the text functionality in all the depth of formative impact. In other words, a formation of a specific culture of linguistic and literary education certainly occurs at the continuity level of becoming by procedural-phased activation of the present theory and methodology in the pre-university, university and post-university education, at the level of the approved conceptual model.

\section{THE EVIDENCE THEORY AND METHODOLOGY OF AXIOLOGICAL COMPLETIONS}

(In the specific cultural interpretation of linguistic and literary education)

The perspective goal:

a) The recovery of datum's unique evidencing crisis in the philological formation;

b) Adaptation to the transcending conditions from the world of textual grammar to the one of literary aesthetics.

The immediate goal:

a) Disclosure of the identity unicity depth in the hermetic - hermeneutic: grammatical interpretation - psychological interpretation;

b) Formative - decisional, evidence of axiological completions.

\section{Establishment of depths of the identity spirit}

Longing, unique interpretive datum, centered on the measurement: autonomy - absolutely.

Longing, a specific - authentic shape of completing evidence.

Longing, emphatic vital-biased cause, representative to the identity triptych:

- $\quad$ pleasure of pain / C. Noica;

- pleasure of giving;

- pleasure of evidence / of resignation / n. $n$.

Longing: hope, faith, cognitive principle, ontological concept, project, process, knowledge - modeling - resignation, unique datum.

The PAG - MECA correlation [13, p. 23-26]

\section{Substitutional functions:}

- Indicator of evidencing completions;

- Specificity of living the authenticity by word; 
- Unitary concept: structural - phenomenal, experiential and experimental;

- Diagnostics - prognostic of completions;

- Prime teleological support - focus on the ideal, on competences;

- $\quad$ Speculative-norming support: beginning on a new stage of becoming;

- Evolutionary-evaluative function;

- Regulatory function;

- Synthesizer function;

\section{The prime function of the PAG-MECA correlation:}

- Epistemic mobilizing process of threefold resignation of the unicity:

I. The being speaks by itself in Kantian manner, beyond appearance. [32]

II. The being speaks phenomenologically-transcedental in Husserl's manner. [29]

III. The being speaks in Mihai Cimpoi's manner, through the vertical of the sovereign inner. [18]

The Evidence Theory and Methodology of Axiological (Figure 1) is required to determine the gradual level of acquisitionimplementation of a specific culture / specific education of linguistic-literary education referring to the actual trends of the performant environment. The confidence in the own strengths for determining the evidence of the present truth it happens because of the focusing over the three principles of the full responsibility inside the classes of linguistic and literary education: The Logical-Semantic and Functional Principle - The Principle of Global Axiology - The Principle of the Sovereign Inner.

\section{THE EVIDENCE THEORY AND METHODOLOGY OF AXIOLOGICAL COMPLETIONS}

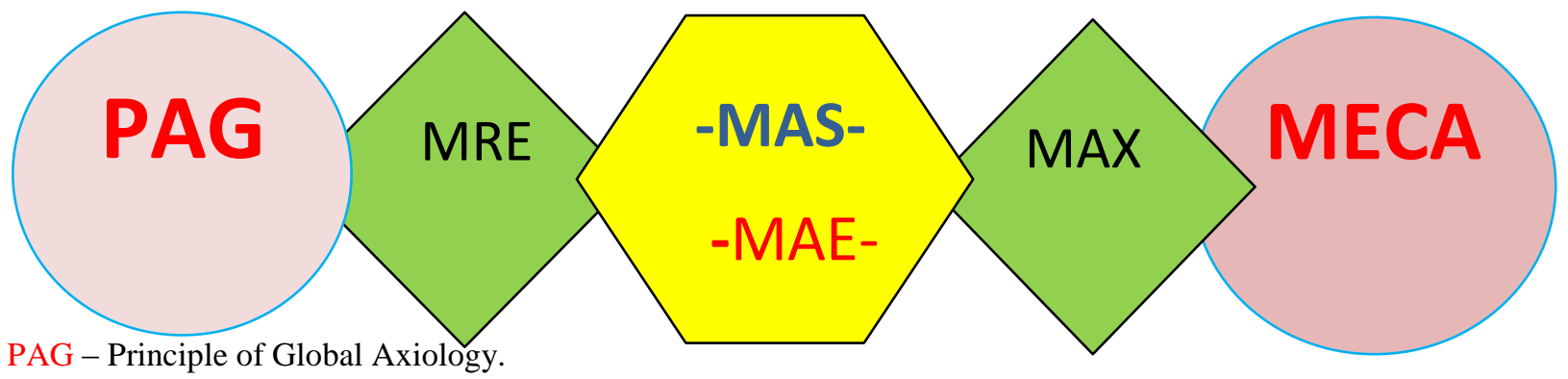

MECA - Evidence Methodology of Axiological Completions.

Interrelation: PAG (cf. L.B.) - PLS/Principle of Sovereign Inner (M. Cimpoi) = PDU/Principle of Human Dignity.

MRE - Method of Returning to Essence Principle of Eternal Return - L. Blaga, M. Eliade.

MAS - Method of Structural Analysis $\}$ Linguistic structuralism: Ferdinand de Saussure = 1. Structural linguistics.

2. Functional linguistics - The School of Prague.

MAE - Method of Emphatic Analysis.

MAX - Method of Axiomatic Analysis.

Completing functions

1 - text - cognitive, energetic, regulatory. 2 - inter-text - speculative, normative, metaphysics

Figure 1: The evidence theory and methodology of axiological completions.

The method of returning to essence / MRE configures the Principle of Eternal Return / M. Eliade, adjusted regularly to the exegeses of the first and to the tenth possibility of PAG / Annex 1.

The method of emphatic analysis / MAE [12, p.17-23] - Method of phenomenological analysis measurement of fitting the self in the giving act.

- $\quad$ Fullness of the meaning of the said and written word;

- $\quad$ The deep sense of the mastered word - intropathical measure of feeling;

- The deep sense as prime netting of weaving the self-content / the value is sense;

- Unequivocal interpretation: grammatical - psychological. [34, p.10] 


\section{The method of emphatic analysis}

ISS N $2278-7690$

Volume $7 \mathrm{Number} 5$

International Journal of Research in Education Methodology

MAE obliges to become aware of:

- The evolutionary - evaluative/self - evaluative correlation, the text-inter-text correlation;

- Intensive valuing: initial, in crescendo, final - reported to the interpretative fullness: verbal communication /nonverbal communication;

- The introphatic - energizing correlation Ratio: author - reciter - spectator / receiver;

- Mobilizing affectivity: phonetical accent - logical accent;

- Sensitive generality: ascending-descending intonation, uniform intonation, hermetic - hermeneutics;

- Effects of oratory art in prose and poetic suspense: prosaic and poetic oratory in suspense: pause, rhyme, rhythm, gestures, mimicry.

\section{The method of structural analysis [13]}

MAS

- Keeping the irreducibility of the text value to the three levels of structural analysis;

- The value of the linguistic unity is not reducible to its signified appearance (to its content or signification), nor to its signifier appearance (its acoustic form or graphics);

- The value of grammatical unit - correlation of specific originality: the author is the text writing itself;

- The Text - valued complex sign.

\section{The method of structural analysis}

MAS focuses on:

- The fundamental principle of structuralism - distinctive principle of internal immanence;

- The synchronous study of logical/grammatical and psychological correlations at the level of collective consciousness;

- The diachronic study of successive relations in the coherent system.

\section{The method of the axiomatic analysis}

MAX assembles the specificity of the conclusive effectiveness in ascending rerun. [13, p. 23-26]

Or, the duplicitous correlation, grammatical subject - quality subject (n. n.) and predication - predicative correlated to the involved subject [15, p.57-62] is one of the prominent evidence: the text itself is written [18].

Therefore, the two poems of Gr. Vieru once analyzed "Longing of mother" and "Morning Song" [14, p.8-15] complement the epistemic core of the entire vieren creation (Vieru's work) from which come off in a fictional-functional way the outlines of the Evidencing Methodology of Axiological Completion in all its determinative complexity: cause - effect. By definition, the whole theory of this methodology is a priority for the Principle of Global Axiology with its ten formative possibilities. (Annex I).

For to elucidate, we bring an example (very ordinary at first glance) of the novel "Leaves of longing" / "Frunze de dor" of the writer lon Druţă: "The trouble leads the man and if Trofimaș does not find his place on the oven, it means that the man has his troubles."

He found in the porch five pennies, but his father didn't wanted to sew for him a little purse to have where to keep his money; they took his boots and brought them to the shoemaker soon as he returned today from the bridge, and in their place, they did not gave him any shoes, and for how long that shoemaker will keep him on the oven - God knows; finally yesterday, he pulled out a nail from the wall, because he needed not especially the nail, and Domnica pulled his ears. [lon Druţă. Leaves of longing. p.13-14]. This is the warning of the spirit state through which is passing any afflicted individual. Trofimaş is upset, feels miserable, due to what, in his turn, causes trouble and sorrow to the people around - as an expression of a confused state of mind, as the logic of the author is also confused in reproducing the feeling. It is the intropathic - convulsive state - caused by / at difficulty. The consequences of an undesirable fact as well as the desirable consequences - are generally the initiative stimulus of druțian imagistic cores, embroidered in supporting the correlation of cause - effect in all the emphatic amplitude. The druţian imaging core, as a center of predicativity [15] represents a particular challenging mode of the character Trofimaş: he has trouble. On the line of subjectivity all the predicates are activated perfectly in one voice: he went, they took, they came back ..., ending with: and Domnica pulled him by the ears! The center of predicativity/ the center of the whole image prediction foreshadows the catalyst center of a specific sort of action in generalizing determination - he has trouble. This particular pre-existential game, of moving the accents in the grammar-psychological interpretation, configures the figure of the great anonymous, having reached the peak condition of expression in the lon Druţă's genius.

The Evidence Theory and Methodology of Axiological Completions, within the class hours, is required to determine perpetually the gradual level of acquisition-implementation of a specific culture of philological formation opposite to the current trends and innovations required by the educational curricula, by the requirements of returning and advancement from the former personalities engaged in this conceptual approach: Ferdinand de Saussure (1857-1913), Edward Sapir (1884 -1939), Emille Berneviste (1902-1976), Leonard Bloomfeld (1887-1949), Roman Jacobson (1896-1982). 
At the timeliness, the confidence in your own powers to determinate the evidence of the truth focuses on the three principles of full responsibility: The Logic-Semantic and Functional Principle/PLSF - The Principle of Global Axiology/PAG - The Principle of Inner Sovereign / PLS interactively activated. The joints of the specific culture of professional education must be those of perspective for looking at the things from / through their essence. Or, an authentic culture of linguistic and literary education, in all the pertinent consistency of the longing, as the first authentic evidence: pain - dedication resignation, must be one full of dignity, of full engagement on the logic-semantic and functional principle, of full involvement on the Principle of Global Axiology - principle of stimulating structural-phenomenal completions in the utility plan: individual - universal: knowing to bear your mandate with dignity. The Principle of the Sovereign Inner, in this responsible engagement, is the one who assumes the appropriate role of polarizing effect: PLSF-PAG.

Or, only to these summaries engages the axiom of vocational re-consignations encoded in Annex 1.

\section{Annex1: principle of graciousness - principle of global axiology}

\section{The possibility of returning to essence:}

- Awareness of the truth of becoming/ "Happiness is to know yourself" / Aristotle;

- Reason and revelation, permanencies of the identity of becoming;

- Promoting the good by what it is: practice of virtue as a global decisive integrity;

- $\quad$ Free will - criterion of responsibilities of self-completions.

\section{The possibility of creative re-consignation of the self:}

- The fusion: labor / game - feast for the soul;

- Personality creating social/cultural values - absolute value;

- $\quad$ Lasting of beauty in the entire plenitude of didactic harmonization;

- Beauty - valuable finality stooped on utility, on sublime.

\section{The possibility of continuous formation:}

- Freedom - perpetual process of identity confirmation: will, reason, purpose;

- Connection to the quality management of training and education;

- The proverbs of Solomon "to know wisdom and instruction"- originality of the interpretative form;

- The XXI century education issues - four (4) defining guidelines of UNESCO;

- Focusing on the Education Code.

\section{The possibility of option:}

- The right to free public expression of opinion by respecting the moral law;

- Recognizing of inter-subjectivity as a sign of respect for the other's freedom;

- Stimulation of exit from under trusteeship: "Have the courage to serve yourself by your own mind"/ I. Kant;

- Re-consignation of a great intellectual culture: law, general interest, debt.

\section{The possibility of self-regulation:}

- The ability to be free is the universal inability of freedom / I. Kant;

- Respecting of objectivity as a general law of open communication and harmonization of differences;

- Recognition of error - a great act of intelligence in order to promote the virtue;

- Reconceptualization of value of knowledge: contradiction, reason/mind, identity;

- The deliberate circulation of the regulating/ self-regulating capacity on the stage of becoming.

\section{The possibility of connection to a common ideal of life:}

- Focus on a common ideal of life

- Human - phenomenon and numen - is not born personality, he becomes personality;

- Connection to the national values and to the universal human values;

- The consecration of the state language as a first value opening the spirituality to universality; 
- Focusing on multiculturalism.

\section{The possibility of ascending trough spirituality:}

- Respecting the scientific truth regarding the moral traditions of intercultural coexistence;

- Deliberate reporting to the dimensions: space / time / way;

- Respecting the special psychic-intellectual structure of the nation that we represent;

- Focusing on the ancestry: Human, horizon of mysteries - Human, horizon of Great Virtues. [10, p.1155]

\section{The possibility of personality re-consignation as global social value:}

- Individual - means and goal of social integration.

- Individuality and phenomenological identity: human - phenomenon and numen;

- Stimulating the love for life by removing the pressure acts and violence;

- Solidarity and equitable economic order;

- Equal rights (between genders) for assertion / affirmation.

\section{The possibility of focus on competences:}

- Knowing how to ingratiate the time value;

- Knowing how to ingratiate the own epistemic configurations;

- Knowing to rise the truth of authenticity to the bar of general axiology;

- Knowing how to love your opponent as your neighbor;

- Knowing how to be resourceful;

- Knowing how to learn to continuously connect to the bar competitiveness;

- Knowing how to ingratiate yourself to the value space - to produce yourself as integral value;

- Knowing how to ingratiate yourself to the ten possibilities of the global axiological principle of Graciousness;

- Knowing how to overcome the barriers of the technological interactive/retroactive framework of education at all degrees and to fit within the sphere/space of the social activism of great virtues;

- Knowing to bear with dignity your divine mandate: HUMAN.

\section{$X$. The possibility of evidencing the axiological completions:}

- The phased reporting to the possibility of returning to the essence;

- Autonomy and Absolute - criteria of evidencing the fullness of the self;

- Parties and the whole at the line of valuable correlation;

- Focusing on the four functions of the philosophy of existence - daily exercise of estimating the truth of knowledge;

- Structural - phenomenology at the line of rewarding correlation: Evidence versus Truth; [35, p.83]

- Correlation PAG - MECA, axiomatic regulatory process of formative evidence.

\section{Conclusions:}

On the path of the entire process of knowledge, between the first possibility of PAG and the tenth, occurs the bounce effort of ascensions through spirituality: Individual - Society. The engagement on the last two exegesis of the Possibility of evidencing the completions by references to the bibliographical notes, characterizes concisely my rich interactivity PAG MECA. In a synthesizer approach, very similar is the fact that "the most advanced way of manifestation of the structuralism is the axiomatic form of scientific theories. It starts from a minimal set of simple assertions, considered true, and a number of derivation rules that allow the construction of complex assertions however, whose truth-value can be determined by binary true or false."[35, p.83] The possibility of evidencing the axiological completions certifies its functionality on the measure of exercising the possibility of staged returning to the essence. Of course, every technical work from the repertoire of targeted methodology, due to the own characteristics of definition becomes a specific measurement of completing evidence, which obliges to essential synthesizing of normative / speculative order: part whole. We underline that each of these methods find their moment and opportune place of taking in target on the dimensions: objectives - finalities, evolution - evaluation, estimation - synthesizing, diagnostics - prognostication; principles, methods, competences; conscious climb to a new level of becoming. The hours of graciousness, starting of 
objectivities and those of free will / evidence of finalities in retroactive availability exercises effectively its own pointing across the entire formative process [7, p.6-11]

If we refer to all the completing prestigious exigencies of Graciousness / of the Principle of General/Global Axiology (as "the second skeleton of human" - "the plan that should lead education" [10. P.1115]) taken together, notably at the possibility of continuous education, we realize that, only a quality education can have continuity, being committed to the traditions of full theoretical and methodological training (Organizational charts I and II). Specifically, if the term key of our concerns - retroactivity - is equivalent to axiom, which, eloquently, means the notion of dignity (by phased returning to the essence - ascension through/by spirituality - evidence of axiological completions), we believe that we do our duty honorably. Or, an authentic culture of linguistic and literary education in all the relevant consistency of longing as the first evidence of the authenticity: pain - dedication - resignation, must be one of full dignity, of full engagement on the global axiological principle - principle of stimulating the structural-phenomenal completions in the integrity plan of morality: knowing to bear your mandate with dignity. The Sovereign Inner Principle, in this responsible commitment, assumes the appropriate role of inter-polarizing effect PLSF - PAG. Introverted / extraverted, the sovereign inner principle intervenes in the role of legislator of positioning oneself in moving direction, opposite to which fact it becomes more utilitarian the evidence in depth of the stylistic trademark of the work, the exceptional quality of the writer. PLSF becomes fully available to the discovery of the mystery hidden in the word on the edge of PLS; PAG - to the punched regulatory motivation of PLS. Finally, the word SINTAXA - namely in this defining formula gains its full engagement: synthesizing the axis values. The inter-relational co-report PAG - PLSF $=$ PLS - total index of evidencing the labor of the self in/by the word. The word / the creation / the text, righteous concept of evidencing the labor of the self at the work of discovering the truth: PLS = PAG. Thus, we define that PLS feeds from PAG at the same level as PAG feeds from PLS, the brand of authenticity evidence belonging, as every time, to PLSF. Or, on the evidence vertical of completions Autonomy - Absolut [1], namely to the principle of sovereign inner / PLS [18] comes the responsibility of determining the self-grouting in the act of building on the vertical correlation PAG - MECA.

Is the fact by which we distinguish the truth that the joints of identity specificity in the proportion "stylistic matrix" of a special nation, and then everyone together, are those of enclosing several principles of sovereign inners on the diagonal verticality...

In a conclusive format, we conclude that The Evidencing Theory and Methodology of Axiological Completions in the process of philological preparation accesses from the beginning on the correlation PAG - MECA versus on objectives purposes / purpose, hence, on the resumption on a new formative stage.

\section{ACKNOWLEDGMENTS}

Our thanks to Liuba V. Botezatu (independent translator), who translated this article and contributed to its publication.

\section{REFERENCES}

1. Andrei, P. 1997. Filosofia valorii. POLIROM, laşi, p.6.

2. Barthes, R. 1965. Elements de semiologie. Gonthier, Paris.

3. Bahtin, M.M. 1979. "Problema teksta v lingvistike, filologii i drugih gumanitarnih naukah. Opit folosofkogo analiza." Iskustvo, 1979.

4. Botezatu, L. 1985. Bogăția și frumusețea limbii materne, în Pedagogul...,10 octombrie, 1985, p. 21-23.

5. Botezatu, L. 1991. Alte modalităti de predare a limbii materne. In Revista de pedagogie si psihologie, Nr.14-16.

6. Botezatu, L. 1997. Rolul Retroacțiunii la evoluarea-evaluarea conținutului formativ în contextul educației lingvistice și literare.Teză pentru susținerea gradului didactic superior, pag 95. Chișinău.

7. Botezatu, L. 2008. Retroacțiunea în educația lingvistică și literar - artistică a elevilor. Comrat, Safin-Grup.

8. Botezatu, L. 2010. Pentru o cultură a educației profesionale axată pe OM. În Revistă de științe socioumane Nr.2, 2010, p. 53-59.

9. Botezatu, L. 2012. The Priorities of the Principle of Graciousness in the professional preparation Versus For a culture of philological education axed on competences, Educational Alternatives, (ISSN 1313-2571), Volume 10, 3-th International Conference "Education, Research \& Development", Bulgaria, http://www.scientific-publications.net

10. Botezatu, L. 2014. The Principle of Global Axiology and The Bipolarized Adequacy of the unique "Datum". Educational Alternatives, Volume 12, 2014, (ISSN 1313-2571). Pages: 1137-1162, http://www.scientificpublications.net/en/article/1000600.

11. Botezatu, L. 2015. The Adverb - Miss Grace of the elegance of our identity. Journal of Advances in linquistics. Vol. 5, No.3, Feb. 2015, page 718 - 722. Council for inovatione Research. www.cirial.com

12. Botezatu, L. 2015. Sintaxa afectivă și metoda analizei emfatice. In Nauka. Obrazovanie. Kulitura. Tom. 2, str. 1623. Komrat. http://kdu.md/images/attachments/sbornik-24-2-2015.pdf

13. Botezatu, L. 2015. Principiul Axiologiei Globale și Metoda Evidenței Complinirilor Axiologice. In Nauka Obrazovanie. Kulitura. Tom. 2, str. 23 - 26, 11 fev., 2015, Komrat. http://kdu.md/images/attachments/sbornik-24-2-2015.pdf

14. Botezatu, L. 2016. Permanențe ale identității cunoașterii - sintaxa și semantica. In Nauka.Obrazovanie. Kulitura. Tom. 2, str. 8-15, 4 fev. 2016, Komrat.

15. Butuc, P. 2012. Studii de gramatică și istorie a limbii române literare, Chișinău.

16. Budagov, P.A. 1984. "Filologhia v sovremennoi boribe idei". Filologhicesschie nauki,1984. N.3.,Str.16.

17. Budagov, P.A. 1985. "Shodstva i neshodstva mejdu rodstvennimi jazikami". Moskva, 1985, str. 23. 
ISSN $2278-7690$

Volume $7 \mathrm{Number} 5$

International Journal of Research in Education Methodology

18. Cimpoi, M. 2015. Nichita Stănescu: logocentrism și ontocentrism - tăcerile și plăcerile textului. În Literatura și Arta, Nr.15, 2015.

19. Ciobanu, A. 1987. Sintaxa și Semantica. Chișinău, Ed. Știința.

20. Coteanu, I. 1990. Gramatică, Stilistică, Compoziție. Ed. Științifică, București.

21. Coşeriu, E. 1994. Textlinguistik. Eine einfürung, Tübingen-Basel, Francke.

22. Dolimar, F. 2003. Globalinaja etica: preodolenie dihotomii "universalism"/"particulearizm". Vorprosi filosofii, 2003, str. 13.

23. De Saussure, F. 1915. Cours de lingvistque generale, Geneva.

24. Feyerabend, P. 1981. Realism, Rationalism and Scientific Method. Psihological Papers, Vol.I, 1981, p.13.

25. Flonta, M., Hans, K. K. 2003. Filosofia practică a lui Kant. POLIROM, 2003.

26. Fontanier, P. 1977 (1821), Les figures du discours, Flammarion, Paris.

27. Găitănaru, Șt. 2012. Subiectul și propoziția subordonată subiectivă.TIPARG.

28. Hegel, Ed. 1979. Fenomenologia spiritului. Bacău.

29. Husserl, E., 1912-1918. Idées directrices pour une phénoménologie. Trad. fr. Gallimard, Paris, 1950.

30. Jung, C. G., Kegan, P. 1972. Syncronicity - An Acausal Conecting Principle.

31. Lande, A. 1991. "Du paralelisme formelle des scientces normatives". Revue de metaphisique et de morale. Juilliet, 1991, p.532.

32. Lecourt, D. 2009. Dicționar de Istoria și Filosofia Științelor, POLIROM, 2009, p. 620-622.

33. Strauss, L. 1978. Antropologia structurală. Editura Politică.

34. Schleiermacher, F.D.E. 2001. Hermeneutica. Colegium. POLIROM 2001.

35. Ștefan Gh. M. 2014. Teoria lui Mihai Drăgănescu. În: Lettre Internationale. Primăvara 2014, p.82-85.

36. Trigg, R. 1996. Înțelegerea științei sociale. Editura științifică.

\section{Author' biography with Photo}

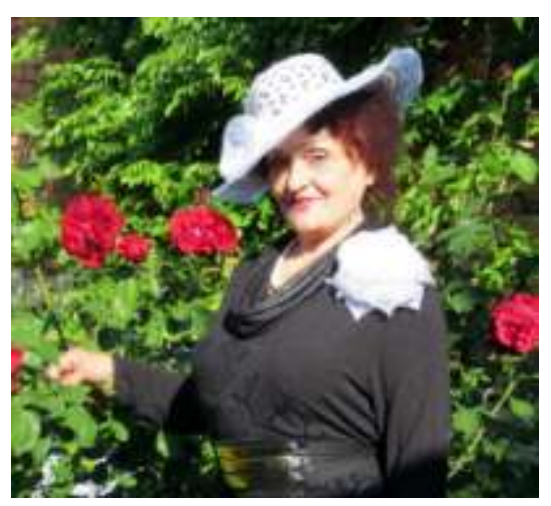

\section{Biography:}

1997 - Thesis of superior academic degree "The role of retroaction on the evolving of formative content in the context of linguistic and literary education" - finality of teaching in secondary education.

2001 - PhD thesis in pedagogy - 13.01.01 "The role of retroaction in the linguistic and literary-artistic education of pupils".

2008 - Two monographs: "Retroaction in the literary and artistic language education of pupils" and "Retroaction and Graciousness in the linguistic and literary-artistic education at the stage of partnership" - same edition "Safin-Group" Ltd., Comrat.

2009 - Scientific Title: Dr. Conf. Univ. Scientific concerns for more than a decade (15 years) at the Department of Romanian philology of the Faculty National Culture, State University of Comrat city- participation in national and international conferences and symposiums in Republic of Moldova, Romania, Ukraine, Russia, Belarus, and Bulgaria. Numerous publications in professional journals of inter-trans-disciplinary nature, methodical guidelines opposite to the investigational experimental preoccupations: The co-report PAG - MECA; PAG - The Principle of General/ Global Axiology and MECA - the Evidencing Methodology of Axiological Completions in the culture of philological training of student: morphology, syntax, literary esthetics, teaching specialty, the theory and the methodology of the educational curricula, linguistic and literary sociology of education, philosophy and axiology of education.

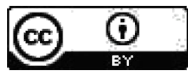

This work is licensed under a Creative Commons Attribution 4.0 International License.

DOI : 10.24297/ijrem.v7i5.4337 